\title{
Modified method for bronchial suture by Ramirez Gama compared to separate stitches suture: experimental study
}

\section{Sutura de brônquios pelo método de Ramirez Gama modificado comparada à sutura com pontos separados: estudo experimental}

Vitor Mayer de Moura'; Erinaldo Rocha Paes Lamdim'; Felipe Souza Ferraz'; Rodrigo Carvalho Turatti, AcCBC-SP1; Carolina de Barros Jaqueta ${ }^{1}$; Pedro Luiz Squilacci Leme, TCBC-SP1

\section{A}

\begin{abstract}
Objective: To experimentally compare two classic techniques described for manual suture of the bronchial stump. Methods: We used organs of pigs, with isolated trachea and lungs, preserved by refrigeration. We dissected 30 bronchi, which were divided into three groups of ten bronchi each, of $3 \mathrm{~mm}, 5 \mathrm{~mm}$, and $7 \mathrm{~mm}$, respectively. In each, we performed the suture with simple, separated, extramucosal stitches in five other bronchi, and the technique proposed by Ramirez and modified by Santos et al in the other five. Once the sutures were finished, the anastomoses were tested using compressed air ventilation, applying an endotracheal pressure of $20 \mathrm{mmHg}$. Results: the Ramirez Gama suture was more effective in the bronchi of 3, 5 and $7 \mathrm{~mm}$, and there was no air leak even after subjecting them to a tracheal pressure of $20 \mathrm{mmHg}$. The simple interrupted sutures were less effective, with extravasation in six of the 15 tested bronchi, especially in the angles of the sutures. These figures were not significant $(p=0.08)$. Conclusion: manual sutures of the bronchial stumps were more effective when the modified Ramirez Gama suture was used in the caliber bronchi arms when tested with increased endotracheal pressure.
\end{abstract}

Key Words: Suture techniques. Bronchi/Surgery. Bronchial fistula.

\section{INTRODUCTION}

T he various techniques used for closure of the bronchial stump after pulmonary resections show that there continues to be controversy regarding this crucial time of such operations. Currently, there is discussion about the superiority of mechanical suture, fundamental when performing endoscopic surgery. But in some situations manual suture and its options are needed, especially when tumors are located near the carina, where there are technical difficulties for employment of the stapler, or if the cartilage of the bronchus is much calcified ${ }^{1}$.

The closing of the bronchus should be performed accurately and with all the refinement of surgical technique. The handling of the structures should avoid unnecessary trauma and excessive devascularization of the bronchial stump that may occur after mediastinal lymphadenectomy 2,3 . The bronchopleural fistula (BPF) is a complication of difficult treatment, with high morbidity and mortality ${ }^{1,4-7}$.

Sweet described the longitudinal closure of the bronchus in $1945^{8}$. The basic purpose of this type of suture is approximate the anterior portion of the structure which has the cartilaginous ring, to its posterior membranous portion ${ }^{4,9}$. The use of a flap of the membranous portion, sectioned more inferiorly than the cartilaginous one, which provides the bronchial stump sutured with the final appearance of a crescent, represents an interesting variant technique, with good results 7,10,11.

Ramirez Gama et al. idealized one invaginating and submucosal suture with concentric stitches, keeping the bronchial stump long ${ }^{12}$. The modification was suggested to strengthen the initial suture stitches in an " $X$ " shape, an option still used due to its satisfactory results. This technique of purse-string suture of the bronchial stump was modified in our country in $1966^{13}$, with good results. Since then, the options of manual suture lost ground and are considered obsolete by some, being indicated only for selected cases ${ }^{14,15}$. Despite all the advances recently achieved, the stapler cannot always be used, and surgeons, in addition to being less fond of conventional sutures, often are forced to manually suture the most difficult stumps ${ }^{10,16}$. Experimentally, the superiority of the stapler been demonstrated when compared with the manual technique in pressure resistance testing 16,17 , as well as its superiority on the bronchial closure without contamination of the pleural cavity when are treated patients with tuberculosis or other infection, and even tumors with necrotic areas ${ }^{10,11}$. 
The purpose of this article was to experimentally compare two classic techniques described for manual suture of the bronchial stump.

\section{METHODS}

For this study we used pig organs, acquired in a refrigerator, with the trachea and lungs preserved by refrigeration.

We dissected 30 bronchi, divided into three groups of ten bronchi each, of $3 \mathrm{~mm}, 5 \mathrm{~mm}$ and $7 \mathrm{~mm}$, respectively. In all groups we employed the suture technique described by Sweet (Figure 1) and the technique proposed by Ramirez Gamma and modified by Santos et al. 8,12,13.

To perform this technique, we start with a purse string suture with extramucosal stitches for half the circumference of the bronchus (Figure 2). All sutures were performed with 3-0 mononylon suture.

Ten $3 \mathrm{~mm}$ bronchi were dissected in the first group, ten $5 \mathrm{~mm}$ ones in the second and ten $7 \mathrm{~mm}$ in the third group. All groups were divided into two subgroups of five bronchi each, and in each group five bronchi were sutured by the technique described by Sweet (Figure 1) and the other five bronchi were sutured by the technique proposed by Ramirez Gama and modified by Santos et al. (Figure 2).

Once the suture was finished, the airway was tested with ventilation, using compressed air via an intubation cannula with an internal diameter of $7.5 \mathrm{~mm}$, connected to the dissected trachea of the animals and attached to a device comprised of a pressure breather and aneroid gauge (Figure 3 ). The sutures were subjected to a maximum endotracheal pressure of 20 $\mathrm{mmHg}$ and externally tested with water to evaluate its effectiveness, confirmed by the absence of air leak. The results were statistically analyzed with the Fisher's exact test.

\section{RESULTS}

Ramirez Gama stitches were more effective in the bronchi of $3 \mathrm{~mm}, 5 \mathrm{~mm}$ and $7 \mathrm{~mm}$, showing no air leak, even after subjecting them to an endotracheal pressure of $20 \mathrm{mmHg}$. The separate single stitches were less effective since there was air leak, particularly at the angles of the sutures, in six of the 15 bronchi sutured with this technique. Among the six who had bronchial air leak, three were from the $5 \mathrm{~mm}$ group, and three from the $7 \mathrm{~mm}$ group. The $3 \mathrm{~mm}$ bronchi group showed no leakage with this technique when subjected to the pressure recommended in the study (Table 1).

The data were then subjected to Fisher's exact test, which returned a value of $p=0.08$. This statistical analysis showed the results not to be significant.

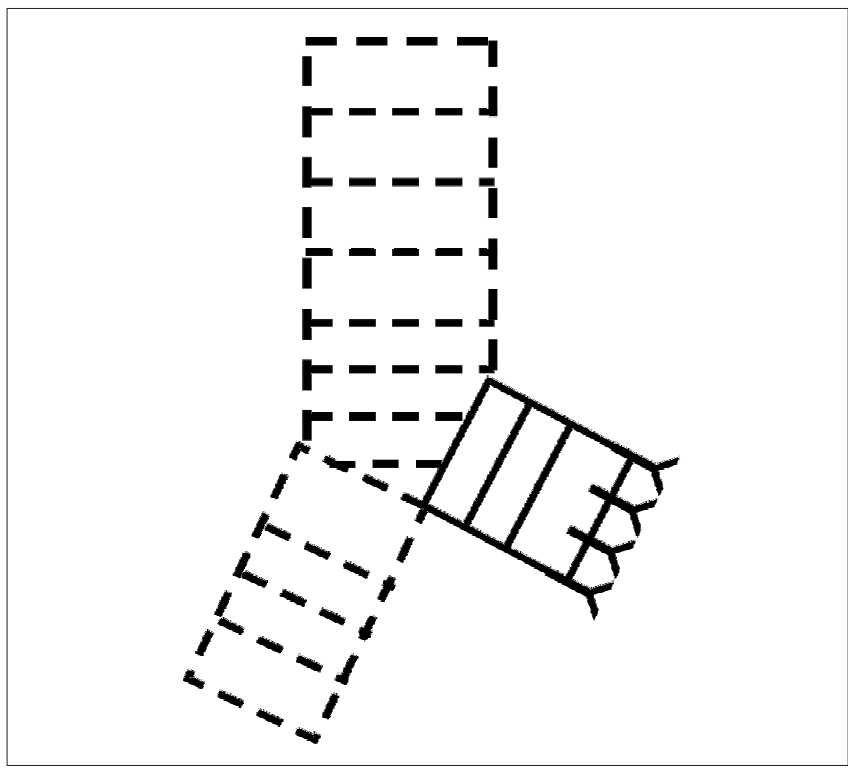

Figure 1 - Scheme of the Sweet technique for closure of the bronchial stump with simple, extramucosal, separated stitches.

\section{DISCUSSION}

Since the late nineteenth century, when the first experimental study on lung resection in rabbits was published in 1881, the death of animals by pericarditis and

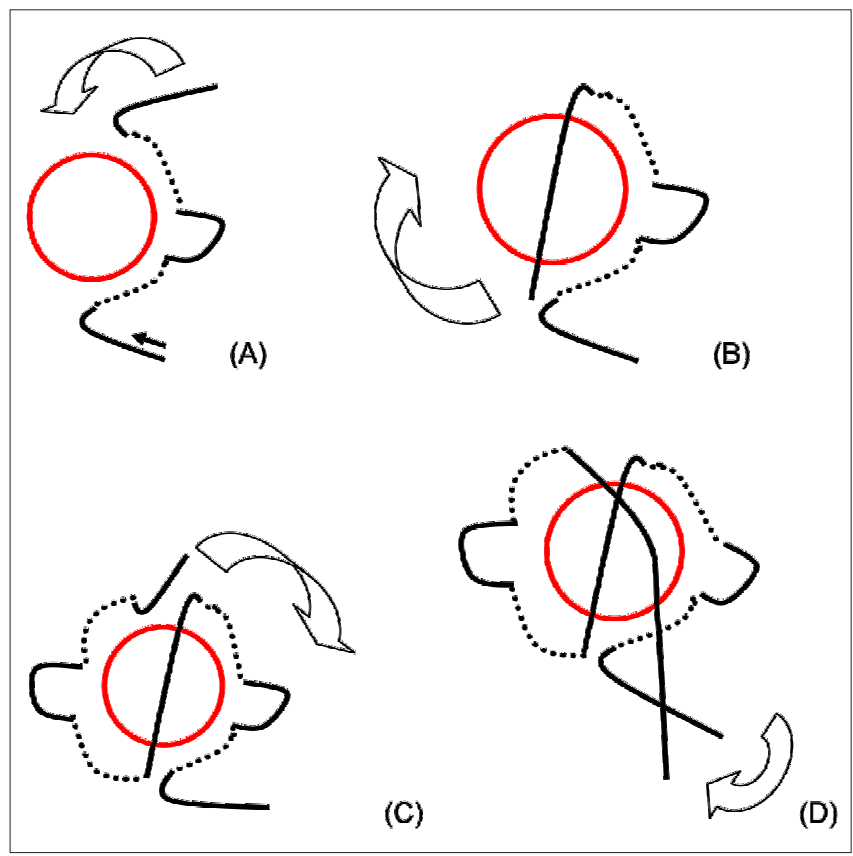

Figure 2 - $\quad$ Ramirez Gama modified suture. (A) the purse string suture starts with extramucosal stitches for half the circumference of the bronchus; $(B)$ the sutured crosses over the lumen of the bronchus; (C) purse string suture is completed in the other half of the circumference of the bronchus; (D) an X-fashion knot is tied, occluding the lumen of the bronchus. 


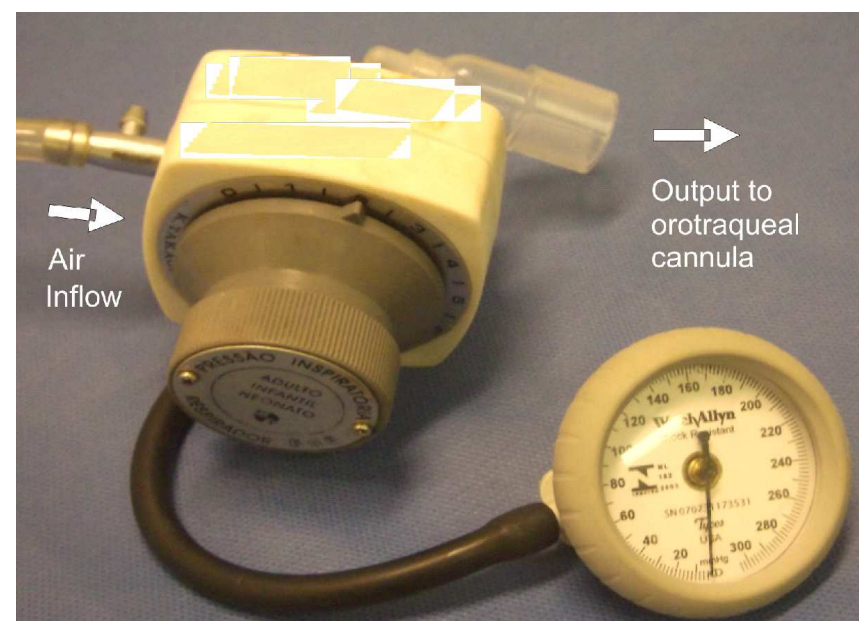

Figure 3 -

Device composed of a pressure respirator and an aneroid gauge to test the endotracheal pressure.

pleural infection was attributed to contamination caused by the opening of the bronchi. Death from infection also occurred when larger animals (dogs) were employed ${ }^{9}$.

In 1908 the separate ligation of hilar structures was proposed. In 1909, Halsted held 21 consecutive thoracotomies, noting only one infection of the thoracic cavity, and described several precautions for proper treatment of the bronchial stump. The concern of reinforcing the suture of the sectioned bronchus with the body's own structures began in the early twentieth century ${ }^{9}$. The first pneumonectomy performed in man was described by Graham in 1933, and in 1945 Sweet advocated the care of the minimum necessary trauma to perform this important suture $7,18,19$, the preservation of blood supply to the bronchial stump, careful approximation of the edges of the sectioned bronchi and reinforcement of the suture. The only significant change to the original description of this technique was leaving the posterior membranous portion longer and its use as a flap to reduce tension on the suture line $4,7,10,14$.

Various tactics describe the importance of a reinforcement on the bronchial suture 2,5 and a range of autologous tissues such as the mediastinal pleura ${ }^{9}$, the pericardium ${ }^{20}$, the fat pad overlying the pericardium ${ }^{2}$, as well as peri-esophageal tissues, the esophagus wall, the omentum and the parietal pleura can be used as the final suture reinforcement. The pedicle of the latissimus dorsi muscle ${ }^{21}$, the flap of intercostal muscle ${ }^{6,11}$, bovine pericardium or biological fibrin glue also have good results $6,11,16,22$

Care should be taken when dissecting and suturing the stump of a bronchus. The delicate handling of structures, respect for the rules of correct surgical technique and the use of atraumatic forceps, especially when clamping the bronchus, are fundamental.

Initially, tissues should not be overly devitalized, with extensive dissection, and electrocoagulation should be avoided. The stump should not be too long to avoid blind funds and the consequent accumulation of secretions 5,17. The stitches should not be too close or too tight, since ischemia is a key factor for the onset of BPF ${ }^{16,23}$. The suture performed with the open proximal bronchi without clamping it is considered an appropriate option, as it is less traumatizing to the supporting tissues ${ }^{7,24}$. The lymph node dissection of the hilum and mediastinum in lung resection for cancer, especially the lymph nodes below the carina, may cause ischemic lesions in the bronchial wall or even an ischemic bronchitis, with significantly increased mortality 3 , now estimated to be between $11 \%$ and $23 \%$ when fistulas occur ${ }^{25}$. These statistics show significant variations among authors; Algar et al. ${ }^{5}$, in 2001, found a morbidity rate of $59 \%$ and mortality of $5.4 \%$ for this complication.

Fistulas occur mainly to the right due to the anatomical conditions of the bronchial tree. The right bronchial stump is more exposed in the pleural space and is not adequately covered by the mediastinal tissues ${ }^{19}$, and the vascularization of the stump leaves it more prone to ischemia ${ }^{3,19}$. The left bronchus naturally ends up being covered by the aorta ${ }^{7}$.

Regarding the optimal method of bronchial stump closure, the controversies and lack of randomized studies hamper conclusions based on statistics. Although many prefer the stapler, there is still room for manual suturing, since not all stumps can be closed with surgical staplers, a situation that occurs when there is extensive calcification of the bronchial cartilage or significant hilar lymphadenopathy. Some authors advocate the manual sutures to minimize the risk of injury to the bronchial microcirculation, and also in tumors very close to the carina ${ }^{10,19}$.

Table 1 - $\quad$ Air leak after the sutures of bronchial stumps with simple, separated stitches and modified Ramirez Gama stitches submitted to an endotracheal pressure of $20 \mathrm{mmHg}$.

\begin{tabular}{lcc}
\hline Diameter of the bronchus & Simple stitches suture & Ramirez Gama stitches \\
\hline $3 \mathrm{~mm}$ & 5 & 5 \\
Air leak & 0 & 0 \\
$5 \mathrm{~mm}$ & 5 & 5 \\
Air leak & $3 \quad(\mathrm{p}=0.08)$ & 0 \\
$7 \mathrm{~mm}$ & $5 \quad$ & 5 \\
Air leak & $3 \quad(\mathrm{p}=0.08)$ & 0 \\
\hline
\end{tabular}


The appearance of the suture granulomas in the light of the sutured stump has been cited by Rienhoff et al., who demonstrated them in autopsy findings 9 . Nonabsorbent sutures, such as silk, not currently used, and polyester should be avoided ${ }^{10}$. Apostolakis et al. cited the appearance of granulomas mainly after manual suture ${ }^{15}$, as proven experimentally ${ }^{26,27}$. A factor to be considered in the airway suture is the triggered inflammatory reaction 26,27 and strictures after the anastomosis ${ }^{13}$. Polypropylene sutures are currently being used in many manual sutures $7,26,27$.

The choice of the value of the maximum pressure used to test the sutures was based on an experimental study that evaluated the pressure required to break the sutured bronchi of dogs when manually closed by the Sweet technique ${ }^{8}$, stating that, on average, manual sutures rupture with a pressure of around $33.71 \mathrm{mmHg}^{16}$. In our study we chose to use a pressure below this already defined average. The results found in this study were not significant $(p=$ 0.08 ), possibly due to sample size, but the values show a trend.

In conclusion, manual sutures of the bronchial stumps were more effective when the modified suture of Ramirez Gama was used in the bronchi of small caliber when tested with increased endotracheal pressure.

\section{Acknowledgements}

To Professor Sergio San Gregorio Favero, for his assistance in the statistical analysis.

\title{
R E S U M O
}

\begin{abstract}
Objetivo: comparar experimentalmente duas técnicas clássicas descritas para a sutura manual do coto brônquico. Métodos: foram empregadas vísceras de suínos com a traqueia e os pulmões isolados, conservados por refrigeração. Foram dissecados 30 brônquios, divididos em três grupos de dez brônquios cada, com $3 \mathrm{~mm}, 5 \mathrm{~mm}$ e $7 \mathrm{~mm}$, respectivamente. Em cada um dos grupos foi realizada a sutura com pontos simples separados extramucosos em cinco brônquios e nos outros cinco, foi empregada a técnica proposta por Ramirez Gama e modificada por Santos et al. Terminadas as suturas, as anastomoses foram testadas com ventilação empregando ar comprimido, submetidas a uma pressão endotraqueal de $20 \mathrm{mmHg}$. Resultados: os pontos de Ramirez Gama foram mais efetivos em brônquios de 3, 5 e $7 \mathrm{~mm}$, e não houve extravasamento de ar mesmo após submetê-los a uma pressão endotraqueal de $20 \mathrm{mmHg}$. Os pontos simples separados foram menos efetivos, havendo extravasamento em seis dos 15 brônquios testados, principalmente nos ângulos das suturas. Estes números não foram significativos $(p=0,08)$. Conclusão: as suturas manuais dos cotos brônquicos foram mais efetivas quando o ponto de Ramirez Gama modificado foi utilizado nos brônquios de pequeno calibre quando testados com aumento da pressão endotraqueal.
\end{abstract}

Descritores: Técnicas de sutura. Brônquios/cirurgia. Fístula brônquica.

\section{REFERENCES}

1. Asamura $\mathrm{H}$, Kondo H, Tsuchiya R. Management of the bronchia stump in pulmonary resections: a review of 533 consecutive recent bronchial closures. Eur J Cardiothorac Surg. 2000;17(2):106-10.

2. Lindner M, Hapfelmeier A, Morresi-Hauf A, Schmidt M, Hatz R, Winter $\mathrm{H}$. Bronchial stump coverage and postpneumonectomy bronchopleural fistula. Asian Cardiovasc Thorac Ann. 2010;18(5):443-9.

3. Satoh Y, Okumura S, Nakagawa K, Horiike A, Ohyanagi F, Nishio $M$, et al. Postoperative ischemic change in bronchial stumps after primary lung cancer resection. Eur J Cardiothorac Surg. 2006:30(1):172-6.

4. Patel RL, Townsend ER, Fountain SW. Elective pneumonectomy: factors associated with morbidity and operative mortality. Ann Thorac Surg. 1992;54(1):84-8.

5. Algar FJ, Alvarez A, Aranda JL, Salvatierra A, Baamonde C, LópezPujol FJ. Prediction of early bronchopleural fistula after pneumonectomy: a multivariate analysis. Ann Thorac Surg. 2001;72(5):1662-7.

6. Gursoy S, Yapucu MU, Ucvet A, Yazgan S, Basok O, Ermete S. Fibrin glue administration to support bronchial stump line. Asian Cardiovasc Thorac Ann. 2008:16(6):450-3.

7. Hubaut JJ, Baron O, Al Habash O, Despins P, Duveau D, Michaud $\mathrm{JL}$. Closure of the bronchial stump by manual suture and incidence of bronchopleural fistula in a series of 209 pneumonectomies for lung cancer. Eur J Cardiothorac Surg. 1999;16(4):418-23.

8. Sweet $\mathrm{RH}$. Closure of the bronchial stump following lobectomy or pneumonectomy. Surgery. 1945;18:82-4.

9. Rienhoff WF, Gannon J, Sherman I. Closure of the bronchus following total pneumonectomy: experimental and clinical observations. Ann Surg. 1942;116(4):481-531.

10. Kakadellis J, Karfis EA. The posterior membranous flap technique for bronchial closure after pneumonectomy. Interact Cardiovasc Thorac Surg. 2008;7(4):638-41.

11. Uçvet A, Gursoy S, Sirzai S, Erbaycu AE, Ozturk AA, Ceylan KC, et al. Bronchial closure methods and risks for bronchopleural fistula in pulmonary resections: how a surgeon may choose the optimum method? Interact Cardiovasc Thorac Surg. 2011;12(4):558-62.

12. Ramirez Gama J, Paz A. La sutura del bronquio en reseccion pulmonar por tuberculosis. Cir Cir. 1962;30:37-48.

13. Santos MIR, Vicente DM, Paternostro CEE, Marçal O. Fechamento brônquico nas ressecções pulmonares. Apresentação dos resultados obtidos em sessenta e um casos com um novo tipo de sutura. Rev Ass Med Bras. 1966;12:151-4.

14. Wright CD, Wain JC, Mathisen DJ, Grillo HC. Postpneumonectomy bronchopleural fistula after sutured bronchial closure: incidence, risk factors, and management. J Thorac Cardiovasc Surg. 1996;112(5):1367-71. 
15. Apostolakis E, Panagopoulos ND, Dougenis D. eComment: Manual closure of bronchial stump during pneumonectomy: an obsolete method for only selective cases. Interact Cardiovasc Thorac Surg. 2008;7(4):641-2.

16. Bof AM, Rapoport A, Paulo DNS, Leiro LCF, Gomes MRA, PandoSerrano RR. Estudo comparativo entre a resistência das suturas manual e mecânica do coto brônquico em cães submetidos à pneumonectomia esquerda. J bras pneumol. 2007;33(2):141-7.

17. Ludwig C, Hoffarth U, Haberstroh J, Schuttler W, Passlick B, Stoelben E. Resistance to pressure of the stump after mechanical stapling or manual suture. An experimental study on sheep main bronchus. Eur J Cardiothorac Surg. 2005;27(4):693-6.

18. Graham EA, Singer JJ. Successful removal of an entire lung for carcinoma of the bronchus. JAMA. 1933;101:1371.

19. Darling GE, Abdurahman A, Yi QL, Johnston M, Waddell TK, Pierre $A$, et al. Risk of a right pneumonectomy: role of bronchopleural fistula. Ann Thorac Surg. 2005;79(2):433-7.

20. Barbetakis N, Samanidis G, Tsilikas C. eComment: Pedicled pericardial flap for prevention of postpneumonectomy bronchopleural fistula. A safe alternative. Interact Cardiovasc Thorac Surg. 2008;7(4):642.

21. Knobloch K, Gohritz A, Vogt PM. eComment: The latissimus dors flap surgery for bronchus stump insufficiency - an alternative? Interact Cardiovasc Thorac Surg. 2008;7(4):642

22. Pereira STLF. Complicações pleurais da cirurgia pulmonar. J Pneumol. 1994;20S: 193

23. Reibscheid SM, Ruiz Jr RL. Bases gerais das ressecções pulmonares. In: Cataneo AJM, Kobayasi S, editores. Clínica Cirúrgica. Rio de Janeiro: Revinter; 2003. p. 40-1.
24. al-Kattan K, Cattalani L, Goldstraw P. Bronchopleural fistula after pneumonectomy with a hand suture technique. Ann Thorac Surg. 1994;58(5):1433-6.

25. Fernandes PP, Jatene FB, Aiello V, Hoshino H, Nakagama G, Miura $F$, et al. Estudo comparativo entre sutura manual em brônquios de cães. J Pneumol. 1990;16(2):71-4.

26. Simões EA, Jatene FB, Stopiglla AJ, Fantoni DT, Guerra JL, Aiello $V D$, et al. Estudo comparativo entre sutura mecânica e manual em brônquios após pneumonectomia esquerda em cães (Canis familiaris): uma avaliação anatomopatológica. Braz J vet Res anim Sci. 2005;42(5):357-66.

27. Bandeira COP, Nigro AJT, Zavadinack Netto M, Prado Filho OR, Sales KP. Comparação da anastomose traqueal suturada com fio absorvível e inabsorvível em coelhos. Acta Sci. 2000;22(2):615-19.

Received on 05/01/2013

Accepted for publication 30/03/2013

Conflict of interest: none.

Source of funding: none.

Address for correspondence:

Mayer Vitor Moura

E-mail: vitor_mayer@hotmail.com 